Jurnal Teknik Komputer AMIK BSI

Volume VI No.1 Januari 2020

P-ISSN 2442-2436, E-ISSN: 2550-0120

Akreditasi Ristekdikti, No: 21/E/KPT/2018

DOI: $10.31294 /$ jtk.v4i2

\title{
Rancang Bangun Sistem Informasi Penjualan Dan Pembelian Alat Tulis Kantor Pada CV. Putra Mandiri
}

\author{
${ }^{1}$ Rifky Permana, ${ }^{2}$ Daning Nur Sulistyowati, ${ }^{3}$ Ani Oktarini Sari, ${ }^{4}$ Tika Adilah Mutiara \\ ${ }^{1,3}$ Sistem Informasi, Teknologi Informasi, Universitas Bina Sarana Informatika, \\ Jl. Kamal Raya No.18 Ringroad Barat, Cengkareng, Jakarta Barat \\ Email: rifky.rpp@bsi.ac.id \\ Email:ani.aos@bsi.ac.id
}

\begin{abstract}
${ }^{2}$ Sistem Informasi, Sekolah Tinggi Ilmu Manajeman Informatika dan Komputer Nusa Mandiri, Jl. Damai No. 8 Warung Jati Barat (Margasatwa) Jakarta Selatan Email: daningnur.dgs@nusamandiri.ac.id
\end{abstract}

${ }^{4}$ Teknologi Informasi, Teknologi Informasi, Universitas Bina Sarana Informatika, Jl. Kamal Raya No.18 Ringroad Barat, Cengkareng, Jakarta Barat Email: tika.tam@bsi.ac.id

\begin{tabular}{ccc}
\hline Diterima & Direvisi & Disetujui \\
$15-11-2019$ & $03-01-2020$ & $02-02-2020$ \\
\hline
\end{tabular}

\begin{abstract}
Abstrak - CV. Putra Mandiri yang bergerak dalam bidang penjualan dan pembelian ATK dan jasa fotocopy ini masih menggunakan sistem secara manual, mulai dari proses pencatatan data barang, sampai penyimpanan datadata lainnya yang berhubungan dengan proses penjualan dan pembelian sampai pembuatan laporan penjualan, laporan pembelian sehingga memungkinkan pada saat proses berlangsung terjadi kesalahan dalam pencatatan, kurang akuratnya laporan dan lamanya dalam pencarian data-data yang diperlukan. Perancangan program merupakan solusi yang terbaik untuk memecahkan permasalahan dalam pelayanan transaksi, pembuatan laporan, mempercepat proses kerja serta kemudahan dalam memperoleh informasi yang setiap saat dibutuhkan. Dari hal tersebut diatas, maka penulis mencoba membantu dengan menggunakan sebagai informasi yang akurat dan efisien. Sehingga dalam melakukan transaksi penjualan lebih baik dibanding dengan sistem manual yang terdahulu
\end{abstract}

\begin{abstract}
CV. Putra Mandiri which is engaged in sales of office stationery and photocopy service its's still using manual program, begin from entry data process, save others file which is related to sale and purchasing process until sales report and purchasing report, when the process run or continue it's enable mistake in registration or entry data. Less accurate report and long time in search file which is needed. The design program is the best solution to solve the problem in transaction service, report, work speed process and easy to get information which is anytime need. Because that, so the author try to keep with as information which is efficient and accurate, so when the sales transaction do, it's better than past manual system.
\end{abstract}

Keywords: Program Design, Sales and Purchasing Programs

\section{PENDAHULUAN}

Perkembangan teknologi komputer semakin pesat dan banyak diminati oleh masyarkat hingga organisasi perusahaan. Hal ini terlihat dari banyaknya kalangan masyarakat hingga perusahaan dari berbagai sektor yang membutuhkan dan tergantung pada pemanfaatan komputer guna mendukung kegiatan sehari-hari. Begitupun untuk perusahaan kecil, menengah mapun besar yang sudah pasti menangani kegiatan proses penggajian setiap bulannya juga sangat membutuhkan penggunaan dan pemanfaatan komputer agar prosesnya dapat berjalan dengan lancar (Taufiq, Carolina, Janti, \& Rachman, 2015).

Dalam dunia usaha seperti usaha perdagangan erat kaitannya dengan transaksi pembelian dan penjualan, yang kegiatan utamanya selalu berhubungan dengan pengolahan data, maka sangat dibutuhkan komputer untuk penyediaan informasi yang cepat dan mempermudah mengorganisasikan data-data yang masuk maupun transaksi yang tercatat. Dengan bantuan sebuah komputer, kegiatan penyimpanan data maupun transaksi tidak lagi dilakukan diatas kertas yang menghabiskan cukup banyak tempat penyimpanan, 
serta bisa mengurangi kehilangan data. (Nurahman, Prasetyo, \& Pratama, 2018)

CV. Putra Mandiri bergerak dalam bidang jasa fotocopy, penjualan dan pembelian ATK secara tunai. Didalam CV. Putra Mandiri tersebut masih terdapat pengolahan data yang belum terkomputerisasi, hal ini sering menimbulkan berbagai permasalahan yang muncul, misalnya untuk mendapatkan informasi tentang data stok barang yang tersedia dan proses perhitungan dalam penjualan dan pembelian ATK secara tunai masih terjadi kesalahan karena masih ditulis dalam faktur. Selain itu proses pembuatan laporan juga masih mengumpulkan arsip penjualan dan pembelian ATK berdasarkan faktur yang ada. Sehingga sering terjadi keterlambatan dalam penyampaian informasi yang dirasakan kurang efektif dan efisien.

\section{METODOLOGI PENELITIAN}

Dalam penulisan ini, metode pengumpulan data yang digunakan adalah :

1. Observasi

Metode ini merupakan cara pengumpulan data secara langsung dengan mengamati objek penelitian dari sejumlah individu dalam jangka waktu yang bersamaan. Observasi suatu aktivitas pengamatan terhadap suatu objek secara cermat dan langsung di lokasi penelitian. Untuk mendapatkan data yang diperlukan penulis menggunakan cara pengamatan langsung pada CV. Putra Mandiri mengenai proses penjualan dan pembelian.

2. Wawancara

Suatu kegiatan percakapan yang direncanakan dan bermanfaat untuk mencapai tujuan tertentu, kegiatan ini dilakukan dengan mewawancarai langsung pihak - pihak yang berwenang yaitu pemilik di CV. Putra Mandiri.

3. Studi Pustaka

Dengan metode ini membantu penulis dalam hal pembuatan jurnal ilmiah yang ditunjang dengan beberapa buku dan literatur yang berkaitan dengan materi yang dibuat dalam penyusunan jurnal ilmiah ini. Pada metode ini penulis mendapat banyak bahan masukan tentang bagaimana merancang atau mengembangkan suatu sistem informasi menurut para ahlinya. Juga pada metode ini penulis membuka, mengambil dan mengutip dari beberapa kutipan para ahli yang berdasarkan dari jurnal ilmiah nasional.

\section{Metode pengembangan perangkat lunak.}

A. Analisa Kebutuhan Sistem

Pada tahap ini penulis membuat Analisa kebutuhan software sesuai dengan kebutuhan untuk pembuatan rancangan sistem penjualan dan pembelian. Agar lebih efisien maka dibuatlah program dengan menggunakan beberapa user.

B. Desain

Pada tahap ini penulis menggunakan rancangan desain database menggunakan MYSQL dalam bentuk bagan $E R D$ dan $L R S$, desain software menggunakan Visual Basic 6 dan Crystal Report. Sedangkan rancangan UML yang digunakan antara lain Activity Diagram, Use Case Diagram, Deployment Diagram, dan Sequence Diagram.

C. Code Generation

Pada tahapan ini penulis akan mengimplementasikannya kedalam aplikasi dengan bahasa pemrograman Microsoft Visual Basic 6.0, MYSQL serta Microsoft Access sebagai Database nya dan program yang dibuat termasuk ke dalam pemrograman terstruktur.

D. Support

Untuk mendukung dalam pembuat program ini, penulis menggunakan Software Microsoft Visual Basic 6.0, database Microsoft Access, dengan komputer bersistem operasi Windows 7 Professional 32bit, processor intel pentium 4, minimal RAM 2GB, minimal Mouse Optic dan Keyboard QWERTY.

\section{A. Sistem Dasar Informasi}

Menurut Darmawan (2013) dalam (Fridayanthie \& Charter, 2016) "Sistem adalah Kumpulan atau group dari bagian komponen apapun baik fisik yang saling berhubungan satu sama lain dan bekerja sama secara harmonis untuk mencapai suatu tujuan"

Menurut (Mulyanto, 2009) "Sistem informasi merupakan suatu komponen yang terdiri dari manusia, teknologi informasi, dan prosedur kerja yang memproses, menyimpan, menganalisis, dan menyebarkan informasi untuk mencapai suatu tujuan".

Menurut (Kristanto, 2008) "Sistem informasi adalah sekumpulan dari prosedur organisasi yang pada saat dilaksanakan akan memberi informasi bagi pengambil keputusan dan untuk mengendalikan organisasi".

Dari beberapa pendapat diatas maka dapat disimpulkan bahwa sistem informasi adalah suatu komponen untuk mengumpulkan data yang diproses menjadi informasi sehingga dapat berguna untuk pengambilan keputusan.

\section{B. Microsoft Visual Basic}

Menurut (Anhar, 2016) "Visual Basic merupakan bahasa pemrograman yang menawarkan Intergrated Development Environment (IDE) visual untuk membuat program perangkat lunak berbasis GUI (Graphical User Interface) pada sistem informasi Microsoft Windows.".

Sedangkan menurut (Elyana, 2017) "Microsoft Visual Basic merupakan sebuah bahasa pemrograman yang menawarkan Integrated 
Development Environment (IDE) visual untuk membuat program perangkat lunak berbasis sistem operasi Microsoft Windows dengan menggunakan model pemrograman (COM)".

\section{Database}

Menurut (Masrur, 2016) "Database adalah sekumpulan file data yang satu sama lainnya saling berhubungan yang diorganisasi sedemikian rupa sehingga memudahkan untuk mendapatkan dan memproses data tersebut". Lingkungan sistem database menekankan pada data yang tergantung (independent) pada aplikasi yang akan menggunakan data tersebut. Data adalah kumpulan-kumpulan fakta dasar (mentah) yang terpisah. Data menggambarkan suatu organisasi.

\section{Crystal Report}

Menurut (Madcoms, 2011) mengemukakan bahwa "Crystal Report merupakan program yang digunakan khusus untuk membuat laporan". Program ini merupakan program yang terpisah dengan Microsoft Visual Basic 6.0, akan tetapi keduanga dapat dihubungkan. Membuat laporan dengan crystal report hasilnya akan lebih baik dan lebih mudah, karena pada crystal report banyak tersedia objek-objek maupun komponen yang mudah digunakan.

\section{E. Penjualan dan Pembelian}

Definisi penjualan menurut (Mulyadi, 2008) "Penjualan merupakan kegiatan yang dilakukan oleh penjual dalam menjual barang atau jasa dengan harapan akan memperoleh laba dari adanya transaksi-transaksi tersebut dan pembelian dapat diartikan sebagai pengalihan atau pemindahan hak kepemilikan atas barang atau jasa dari pihak penjual ke pembeli".

\section{F. Unified Modelling Language (UML)}

Menurut (Sukamto \& Shalahuddin, 2014) “ $U M L$ (Unified Modelling Languange) "adalah salah satu standar bahasa yang banyak digunakan di dunia industri untuk mendefinisikan requirement, membuat analis dan desain serta menggambarkan arsitektur dalam pemrograman berorientasi objek".

Adapun diagram-diagram yang ada didalam $U M L$ adalah sebagai berikut:

a. Use Case Diagram

Menurut (Sukamto \& Shalahuddin, 2014) "Yang dimaksud dengan use case adalah pemodelan untuk kelakuan (behavior) sistem informasi yang akan dibuat."

b. Activity Diagram

Menurut (Sukamto \& Shalahuddin, 2014) "Diagram aktivitas atau activity diagram menggambarkan workflow (aliran kerja) atau aktivitas dari sebuah sistem atau proses bisnis". c. Deployment Diagram

Menurut (Sukamto \& Shalahuddin, 2014)

"Diagram deployment atau deployment diagram menunjukan konfigurasi komponen dalam proses eksekusi aplikasi”.

d. Component Diagram

Menurut (Sukamto \& Shalahuddin, 2014)

"Diagram komponen atau component diagram dibuat untuk menunjukan organisasi dan ketergantungan diantara kumpulan komponen dalam sebuah sistem".

\section{G. Entity Relationship Diagram (ERD)}

Menurut (Ladjamuddin, 2013) menyatakan bahwa "Entity Relation Diagram (ERD) adalah suatu model jaringan yang menggunakan susunan data yang disimpan dalam sistem secara abstrak".

\section{H. Logical Record Structure (LRS)}

Menurut Tabrani (2014) dalam (Kuryanti, 2016) Logical Record Structure (LRS) dibentuk dengan nomor dari tipe record. Beberapa tipe record digambarkan oleh kotak persegi panjang dan dengan nama yang unik. Perbedaan LRS dengan E-R diagram adalah nama tipe record berada diluar kotak field tipe record ditempatkan. LRS terdiri dari linklink diantara tipe record. Link ini menunjukkan arah dari satu tipe record field-field yang kelihatan pada kedua link tipe record. Penggambaran LRS mulai dengan menggunakan model yang dimengerti.

Menurut (Fridayanthie \& Mahdiati, 2016) "Logical Record Structure (LRS) adalah representasi dari struktur record-record pada tabel-tabel yang terbentuk dari hasil antar himpunan entitas".

\section{HASIL DAN PEMBAHASAN}

CV. PUTRA MANDIRI didirikan oleh Bapak Wiradi dan Bapak Yugianto pada tanggal 9 Juni 2009 terletak diwilayah Menteng Atas, Jakarta Selatan. Berawal dari pengalamannya Bapak Wiradi adalah seorang Desain Grafis dan Bapak Yugianto adalah seorang Teknisi (operator), CV. PUTRA MANDIRI bergerak dibidang percetakan yang fokus usahanya yaitu jasa fotocopy, alat tulis kantor. Pertama kali usaha yang dijalankan percetakan ini hanya bisa menyewa 1 unit mesin untuk memproduksi barang-barang cetakan, lama kelamaan sistem sewa mesin pun berganti menjadi sistem sewa kredit. Sekarang percetakan ini sudah memiliki 5 unit mesin fotocopy biasa, 1 unit mesin fotocopy berwarna, 1 unit mesin pemotong kertas, 1 unit mesin laminating, dan 3 unit mesin fotocopy ukuran kecil sebagai inventaris pribadi percetakan.

\section{Proses Bisnis Sistem Berjalan}

Sebelum bagian pembelian membeli barang, terlebih dahulu bagian gudang melakukan pengecekan barang, bila ada barang yang habis bagian gudang 
memberikan data barang yang harus dibeli ke bagian pembelian, kemudian bagian pembelian melakukan pembelian secara tunai kepada supplier, sebagai bukti pembelian bagian pembelian menerima dokumen surat jalan dari supplier. Pelanggan datang langsung untuk membeli barang, kemudian sebagai bukti penjualan barang bagian penjualan akan menyerahkan tanda terima kepada pelanggan. Setiap akhir bulan masing-masing bagian akan membuat laporan, yaitu bagian pembelian akan membuat laporan pembelian barang dan bagian penjualan akan membuat laporan penjualan barang yang akan diserahkan ke direktur.

\section{Activity Diagram}

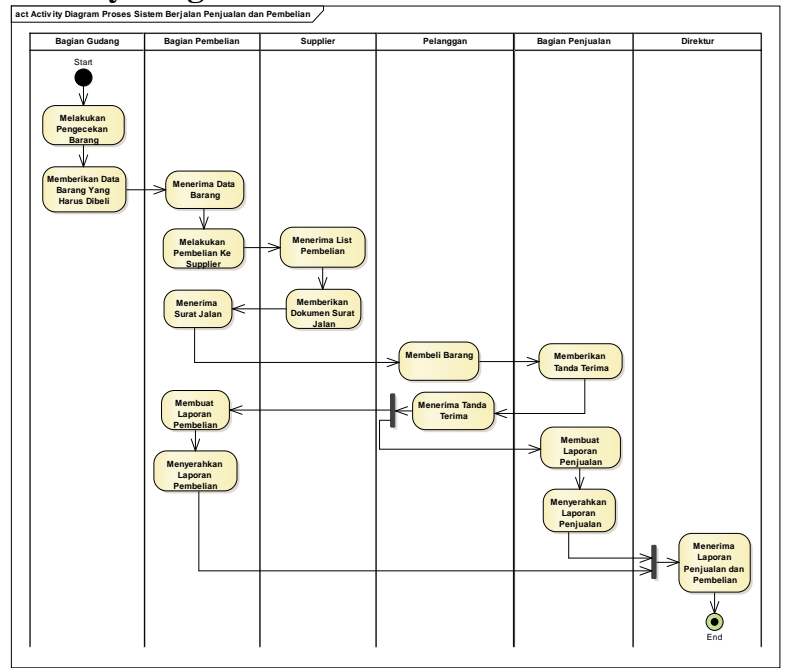

Sumber : Hasil Penelitian

Gambar 1. Activity Diagram Prosedur Sistem Berjalan

\section{Analisa Kebutuhan}

Sistem penjualan dan pembelian alat tulis kantor pada CV. PUTRA MANDIRI belum terkomputerisasi, agar lebih efisien maka dibuatlah program dengan menggunakan beberapa user. Berikut ini analisa kebutuhan (analyst requirement) dari program sistem penjualan dan pembelian alat tulis kantor tersebut.

Akses Administrator

A.1 Administrator Dapat Login

A.2 Administrator Dapat Mengolah Data Barang

A.3 Administrator Dapat Mengolah Data Customer

A.4 Administrator Dapat Mengolah Data Pengguna

A.5 Administrator Dapat Mengolah Data Perkiraan

A.6 Administrator Dapat Mengolah Data Supplier

A.7 Administrator Dapat Memproses Transaksi

Penjualan

A.8 Administrator Dapat Memproses Transaksi Pembelian

A.9 Administrator Dapat Memproses Transaksi Jurnal Umum

A.10 Administrator Dapat Mencetak Laporan Data
Barang

A.11 Administrator Dapat Mencetak Laporan Data Customer

A.12 Administrator Dapat Mencetak Laporan Data Supplier

A.13 Administrator Dapat Mencetak Laporan Penjualan

A.14 Administrator Dapat Mencetak Laporan Pembelian

A.15 Administrator Dapat Mencetak Laporan Jurnal Umum

A.16 Administrator Dapat Logout

Akses Bagian Penjualan

B.1 Bagian Penjualan Dapat Login

B.2 Bagian Penjualan Dapat Memproses Transaksi Penjualan

B.3 Bagian Penjualan Dapat Mencetak Laporan Data Customer

B.4 Bagian Penjualan Dapat Mencetak Laporan Penjualan

B.5 Bagian Penjualan Dapat Logout

Akses Bagian Pembelian

C.1 Bagian Pembelian Dapat Login

C.2 Bagian Pembelian Dapat Memproses Transaksi Pembelian

C.3 Bagian Pembelian Dapat Mencetak Laporan Data Barang

C.4 Bagian Pembelian Dapat Mencetak Laporan Data Supplier

C.5 Bagian Pembelian Dapat Mencetak Laporan Pembelian

C.6 Bagian Pembelian Dapat Logout

\section{Use Case Diagram}

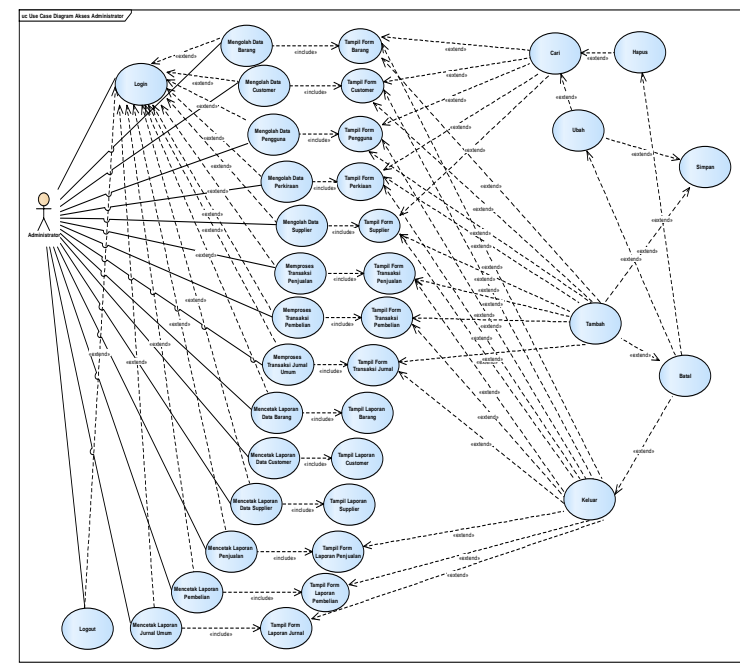

Sumber : Hasil Penelitian

Gambar 2. Use Case Diagram Akses Administrator 
Tabel 1. Deskripsi Use Case Akses Administrator

\begin{tabular}{|c|c|}
\hline \multicolumn{2}{|c|}{ Use Case Narative Akses Administrator } \\
\hline Tujuan & $\begin{array}{l}\text { Aktor dapat melihat data } \\
\text { yang ada pada akses } \\
\text { Administrator }\end{array}$ \\
\hline Deskripsi & $\begin{array}{l}\text { Sistem ini memungkinkan } \\
\text { aktor untuk dapat } \\
\text { mengakses mengolah data } \\
\text { barang, mengolah data } \\
\text { customer, mengolah data } \\
\text { pengguna, mengolah data } \\
\text { perkiraan, mengolah data } \\
\text { supplier, memproses } \\
\text { transaksi penjualan, } \\
\text { memproses transaksi } \\
\text { pembelian, memproses } \\
\text { transaksi jurnal umum, } \\
\text { melihat dan mencetak } \\
\text { laporan data barang, laporan } \\
\text { data customer, laporan data } \\
\text { supplier, laporan penjualan, } \\
\text { laporan pembelian, laporan } \\
\text { jurnal umum lewat aplikasi } \\
\text { program }\end{array}$ \\
\hline \multicolumn{2}{|l|}{ Skenario Utama } \\
\hline Aktor & Admi \\
\hline Kondisi Awal & $\begin{array}{l}\text { Aktor membuka aplikasi } \\
\text { akses Administrator }\end{array}$ \\
\hline Aksi Aktor & Reaksi Sistem \\
\hline $\begin{array}{lr}\text { 1. Aktor } & \text { memilih } \\
\text { mengolah } & \text { data } \\
\text { barang } & \\
\end{array}$ & $\begin{array}{l}\text { Sistem ini menampilkan } \\
\text { informasi mengolah data } \\
\text { barang }\end{array}$ \\
\hline $\begin{array}{lr}\begin{array}{l}\text { 2. Aktor } \\
\text { mengolah } \\
\text { customer }\end{array} & \text { data } \\
\end{array}$ & $\begin{array}{l}\text { Sistem ini menampilkan } \\
\text { informasi mengolah data } \\
\text { customer }\end{array}$ \\
\hline $\begin{array}{lr}\text { 3. Aktor } & \text { memilih } \\
\text { mengolah } & \text { data } \\
\text { pengguna } & \\
\end{array}$ & $\begin{array}{l}\text { Sistem ini menampilkan } \\
\text { informasi mengolah data } \\
\text { pengguna }\end{array}$ \\
\hline $\begin{array}{lr}\text { 4. Aktor } & \text { memilih } \\
\text { mengolah } & \text { data } \\
\text { perkiraan } & \\
\end{array}$ & $\begin{array}{l}\text { Sistem ini menampilkan } \\
\text { informasi mengolah data } \\
\text { perkiraan }\end{array}$ \\
\hline $\begin{array}{lr}\text { 5. Aktor } & \text { memilih } \\
\text { mengolah } & \text { data } \\
\text { supplier } & \\
\end{array}$ & $\begin{array}{l}\text { Sistem ini menampilkan } \\
\text { informasi mengolah data } \\
\text { supplier }\end{array}$ \\
\hline $\begin{array}{lr}\begin{array}{l}\text { 6. Aktor } \\
\text { proses } \\
\text { penjualan }\end{array} & \text { transaksi } \\
\end{array}$ & $\begin{array}{l}\text { Sistem ini menampilkan } \\
\text { informasi proses transaksi } \\
\text { penjualan }\end{array}$ \\
\hline $\begin{array}{lr}\text { 7. Aktor memilih } \\
\text { proses } \\
\text { pembelian }\end{array}$ & $\begin{array}{l}\text { Sistem ini menampilkan } \\
\text { informasi proses transaksi } \\
\text { pembelian }\end{array}$ \\
\hline $\begin{array}{lr}\text { 8. Aktor } & \text { memilih } \\
\text { proses } & \text { transaksi } \\
\text { jurnal } & \end{array}$ & $\begin{array}{l}\text { Sistem ini menampilkan } \\
\text { informasi proses transaksi } \\
\text { jurnal }\end{array}$ \\
\hline $\begin{array}{l}\text { 9. Aktor memilih } \\
\text { proses melihat dan } \\
\text { mencetak laporan } \\
\text { data barang }\end{array}$ & $\begin{array}{l}\text { Sistem ini menampilkan } \\
\text { informasi melihat dan } \\
\text { mencetak laporan data } \\
\text { barang }\end{array}$ \\
\hline $\begin{array}{r}\text { 10. Aktor memilih } \\
\text { proses melihat dan } \\
\text { mencetak laporan }\end{array}$ & $\begin{array}{ll}\text { Sistem ini menampilkan } \\
\text { informasi melihat dan } \\
\text { mencetak laporan data }\end{array}$ \\
\hline
\end{tabular}

\begin{tabular}{|c|c|}
\hline data Customer & Customer \\
\hline $\begin{array}{l}\text { 11. Aktor memilih } \\
\text { proses melihat dan } \\
\text { mencetak laporan } \\
\text { data supplier }\end{array}$ & $\begin{array}{llr}\text { Sistem ini } & \text { menampilkan } \\
\text { informasi } & \text { melihat dan } \\
\text { mencetak } & \text { laporan data } \\
\text { supplier } & & \\
\end{array}$ \\
\hline $\begin{array}{l}\text { 12. Aktor memilih } \\
\text { proses melihat dan } \\
\text { mencetak laporan } \\
\text { penjualan }\end{array}$ & $\begin{array}{l}\text { Sistem ini menampilkan } \\
\text { informasi melihat dan } \\
\text { mencetak laporan penjualan }\end{array}$ \\
\hline $\begin{array}{l}\text { 13. Aktor memilih } \\
\text { proses melihat dan } \\
\text { mencetak laporan } \\
\text { pembelian }\end{array}$ & \begin{tabular}{lr} 
Sistem ini & menampilkan \\
informasi & melihat dan \\
mencetak & \multicolumn{2}{c}{ laporan } \\
pembelian & \multicolumn{2}{c}{}
\end{tabular} \\
\hline $\begin{array}{l}\text { 14. Aktor memilih } \\
\text { proses melihat dan } \\
\text { mencetak laporan } \\
\text { jurnal }\end{array}$ & $\begin{array}{l}\text { Sistem ini menampilkan } \\
\text { informasi melihat dan } \\
\text { mencetak laporan jurnal }\end{array}$ \\
\hline Kondisi Akhir & $\begin{array}{l}\text { Jika perintah sesuai maka } \\
\text { sistem akan menampilkan } \\
\text { apa yang diinginkan }\end{array}$ \\
\hline
\end{tabular}

Sumber : Hasil Penelitian

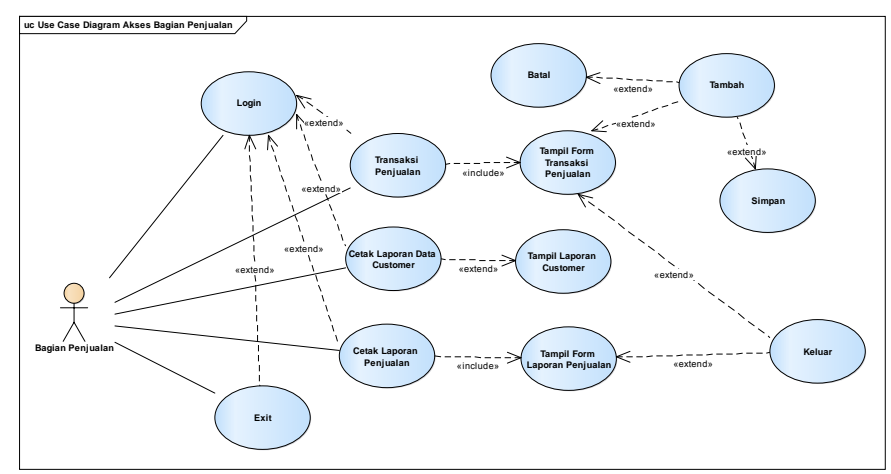

Sumber : Hasil Penelitian

Gambar 3. Use Case Diagram Akses Bagian Penjualan

Tabel 2. Deskripsi Use Case Akses Bagian Penjualan

\begin{tabular}{|l|l|}
\hline \multicolumn{2}{|c|}{ Use Case Narative Akses Bagian Penjualan } \\
\hline Tujuan & $\begin{array}{l}\text { Aktor dapat melihat data } \\
\text { yang ada pada akses Bagian } \\
\text { Penjualan }\end{array}$ \\
\hline Deskripsi & $\begin{array}{l}\text { Sistem ini memungkinkan } \\
\text { aktor untuk dapat } \\
\text { mengakses memproses } \\
\text { transaksi penjualan, } \\
\text { mencetak laporan data } \\
\text { customer, mencetak laporan } \\
\text { penjualan lewat aplikasi } \\
\text { program }\end{array}$ \\
\hline Skenario Utama & \multicolumn{2}{|c|}{ Bagian Penjualan } \\
\hline Aktor & $\begin{array}{l}\text { Aktor membuka aplikasi } \\
\text { akses Bagian Penjualan }\end{array}$ \\
\hline $\begin{array}{l}\text { Kondisi Awal } \\
\text { Reaksi Sistem }\end{array}$ \\
\hline Aksi Aktor & $\begin{array}{l}\text { Sistem ini menampilkan } \\
\text { informasi proses transaksi }\end{array}$ \\
\hline $\begin{array}{l}\text { 1. Aktor memilih } \\
\text { memproses }\end{array}$ &
\end{tabular}




\begin{tabular}{|c|c|}
\hline transaksi penjualan & penjualan \\
\hline $\begin{array}{l}\text { 2. Aktor memilih } \\
\text { mencetak laporan } \\
\text { data customer }\end{array}$ & $\begin{array}{l}\text { Sistem ini menampilkan } \\
\text { informasi melihat dan } \\
\text { mencetak laporan data } \\
\text { customer }\end{array}$ \\
\hline $\begin{array}{l}\text { 3. Aktor memilih } \\
\text { mencetak laporan } \\
\text { penjualan }\end{array}$ & $\begin{array}{l}\text { Sistem ini menampilkan } \\
\text { informasi melihat dan } \\
\text { mencetak laporan penjualan }\end{array}$ \\
\hline Kondisi Akhir & $\begin{array}{l}\text { Jika perintah sesuai maka } \\
\text { sistem akan menampilkan } \\
\text { apa yang diinginkan }\end{array}$ \\
\hline
\end{tabular}

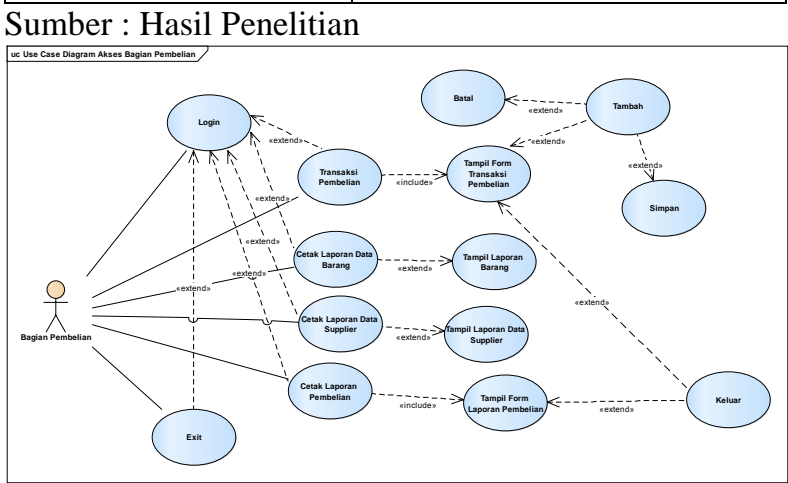

Sumber : Hasil Penelitian

Gambar 4. Use Case Diagram Akses Bagian Pembelian

Tabel 3. Deskripsi Use Case Akses Bagian Pembelian

\begin{tabular}{|c|c|}
\hline \multicolumn{2}{|c|}{ Use Case Narative Akses Bagian Pembelian } \\
\hline Tujuan & $\begin{array}{l}\text { Aktor dapat melihat data } \\
\text { yang ada pada akses Bagian } \\
\text { Pembelian }\end{array}$ \\
\hline Deskripsi & $\begin{array}{l}\text { Sistem ini memungkinkan } \\
\text { aktor untuk dapat mengakses } \\
\text { memproses transaksi } \\
\text { pembelian, mencetak laporan } \\
\text { data barang, mencetak } \\
\text { laporan data supplier, } \\
\text { mencetak laporan pembelian } \\
\text { lewat aplikasi program }\end{array}$ \\
\hline \multicolumn{2}{|l|}{ Skenario Utama } \\
\hline Aktor & Bagian Pembelian \\
\hline Kondisi Awal & $\begin{array}{l}\text { Aktor membuka aplikasi } \\
\text { akses Bagian Pembelian }\end{array}$ \\
\hline Aksi Aktor & Reaksi Sistem \\
\hline $\begin{array}{l}\text { 1. Aktor memilih } \\
\text { memproses } \\
\text { transaksi pembelian }\end{array}$ & $\begin{array}{l}\text { Sistem ini menampilkan } \\
\text { informasi proses transaksi } \\
\text { pembelian }\end{array}$ \\
\hline $\begin{array}{lr}\text { 2. Aktor memilih } \\
\text { mencetak laporan } \\
\text { data barang }\end{array}$ & $\begin{array}{l}\text { Sistem ini menampilkan } \\
\text { informasi melihat dan } \\
\text { mencetak laporan data barang }\end{array}$ \\
\hline $\begin{array}{l}\text { 3. Aktor memilih } \\
\text { mencetak laporan } \\
\text { data supplier }\end{array}$ & \begin{tabular}{lrr} 
Sistem ini & \multicolumn{2}{r}{ menampilkan } \\
informasi & melihat dan \\
mencetak & laporan data \\
supplier & & \\
\end{tabular} \\
\hline $\begin{array}{l}\text { 4ktor memilih } \\
\text { mencetak }\end{array}$ & $\begin{array}{l}\text { Sistem ini } \begin{array}{l}\text { menampilkan } \\
\text { informasi }\end{array} \text { melihat dan } \\
\end{array}$ \\
\hline
\end{tabular}

\begin{tabular}{|c|l|}
\hline pembelian & mencetak laporan pembelian \\
\hline Kondisi Akhir & $\begin{array}{l}\text { Jika perintah sesuai maka } \\
\text { sistem akan menampilkan } \\
\text { apa yang diinginkan }\end{array}$ \\
\hline
\end{tabular}

Sumber : Hasil Penelitian

Entity Relationship Diagram (ERD)

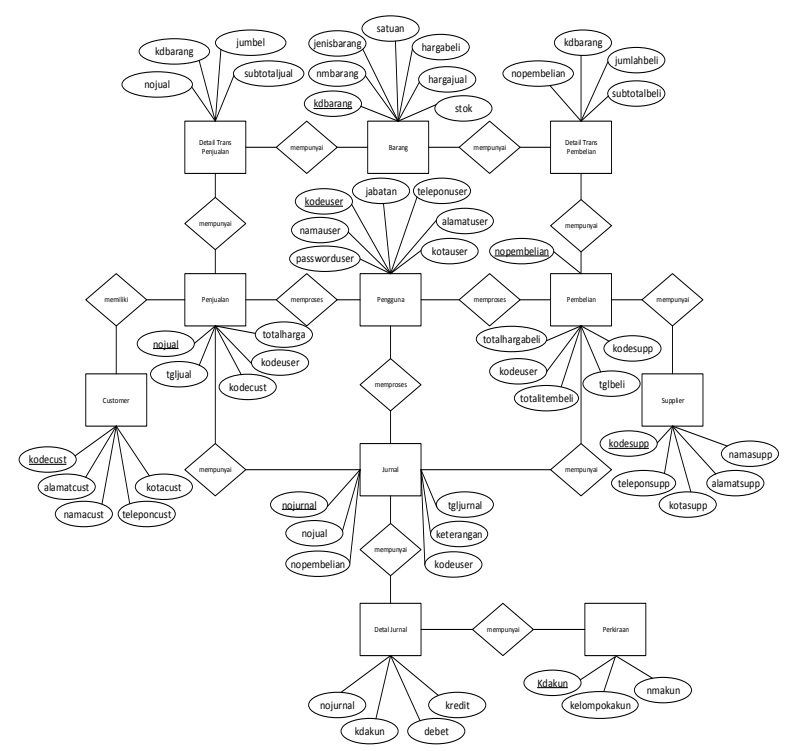

Sumber : Hasil Penelitian

Gambar 5. Entity Relationship Diagram

\section{Logical Record Structure (LRS)}

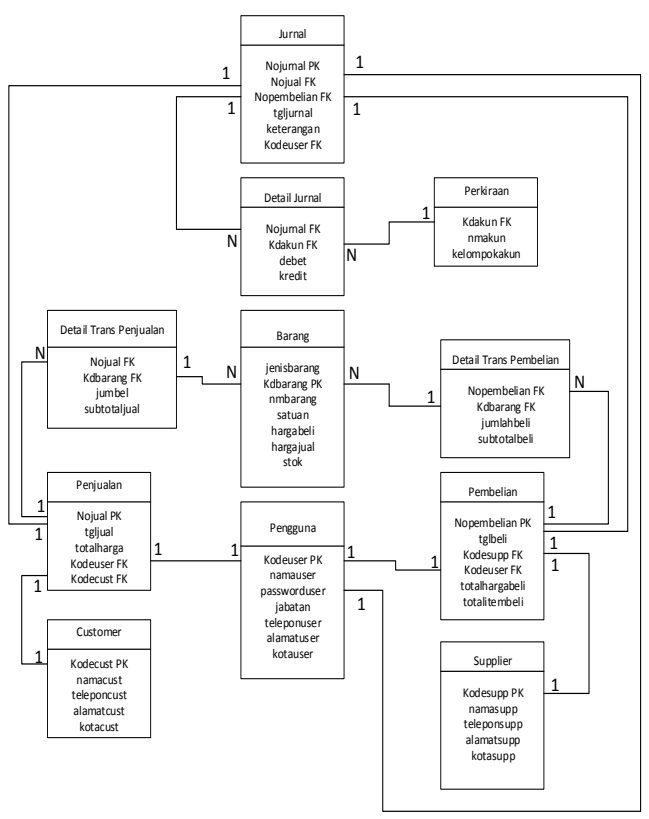

Sumber : Hasil Penelitian

Gambar 6. Logical Record Structure 


\section{Deployment Diagram}

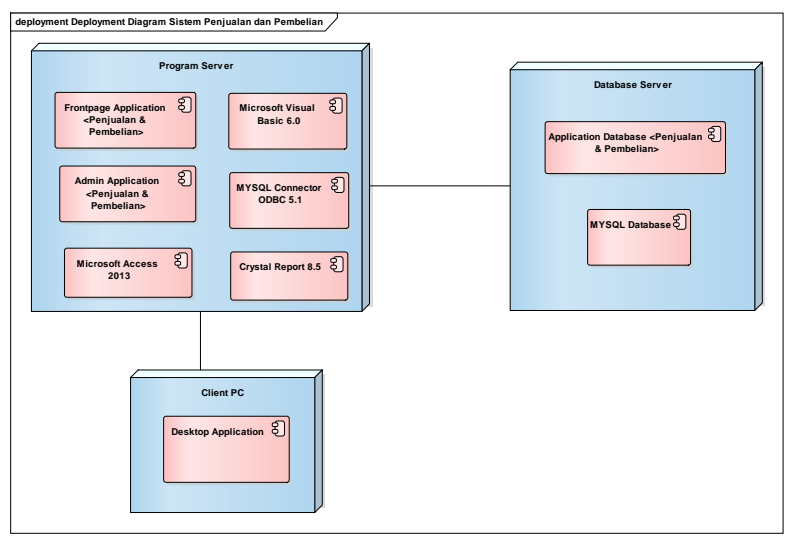

Sumber : Hasil Penelitian

Gambar 7. Deployment Diagram

\section{User Interface}

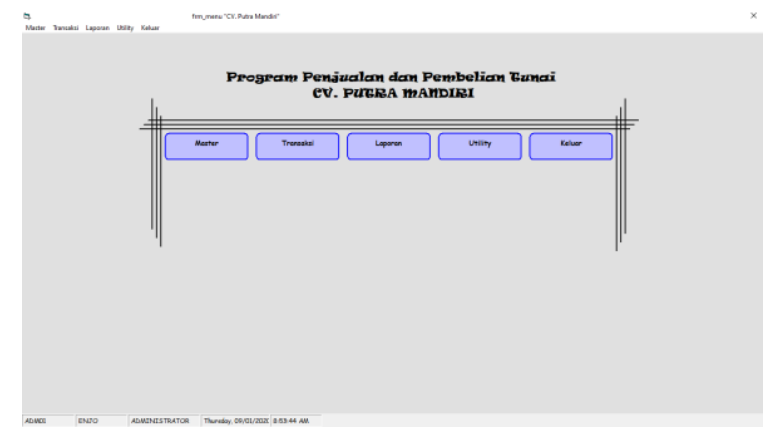

Sumber : Hasil Penelitian

Gambar 8. Tampilan Form Menu Utama

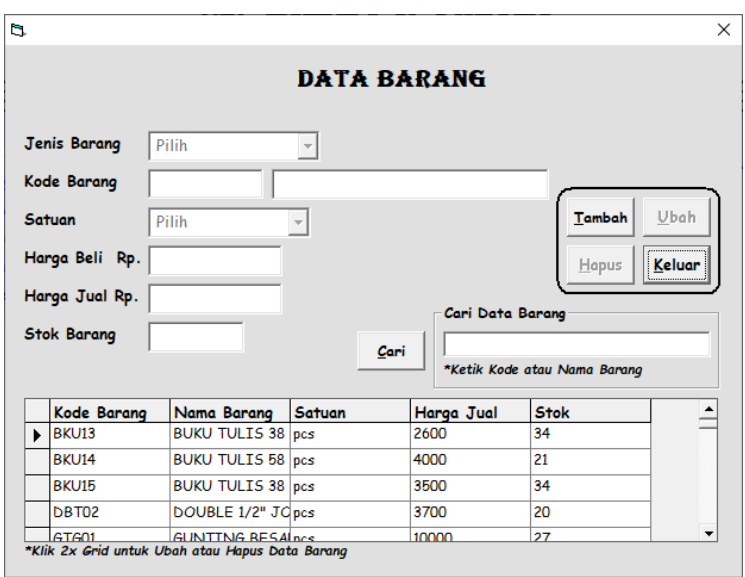

Sumber : Hasil Penelitian

Gambar 9. Tampilan Form Data Barang

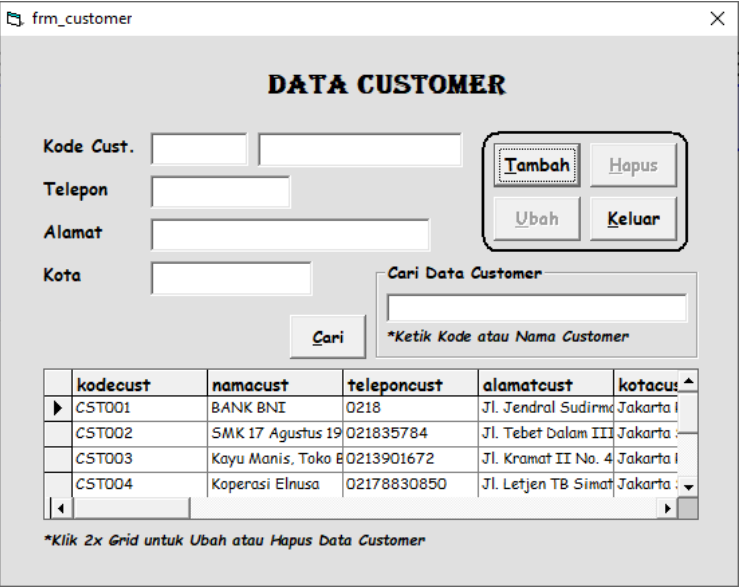

Sumber : Hasil Penelitian

Gambar 10. Tampilan Form Data Customer

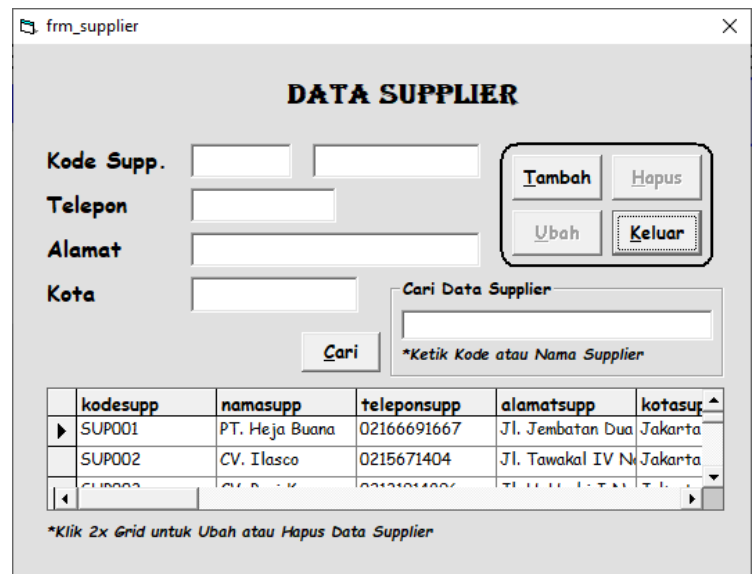

Sumber : Hasil Penelitian

Gambar 11. Tampilan Form Data Supplier

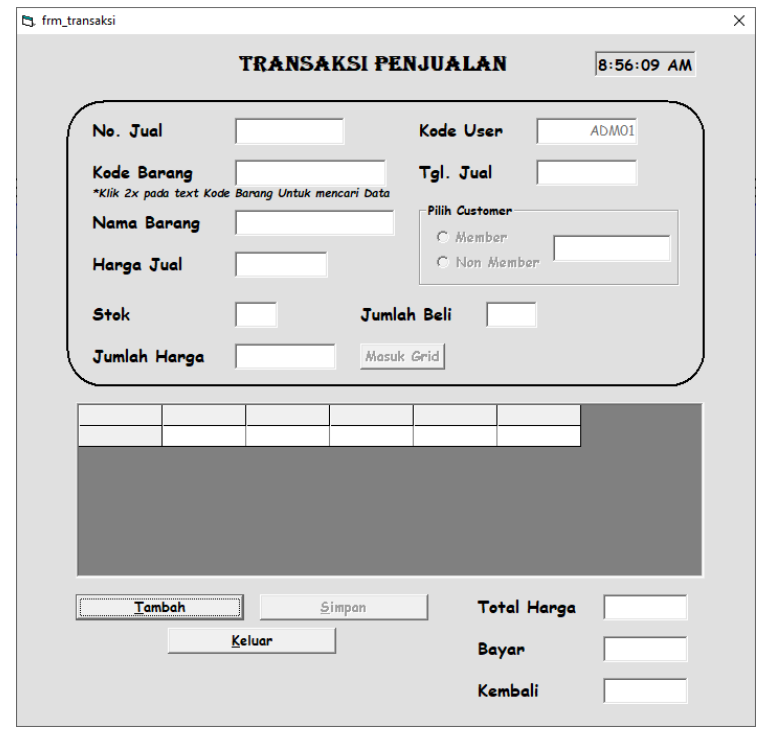

Sumber : Hasil Penelitian

Gambar 12. Tampilan Form Transaksi Penjualan 


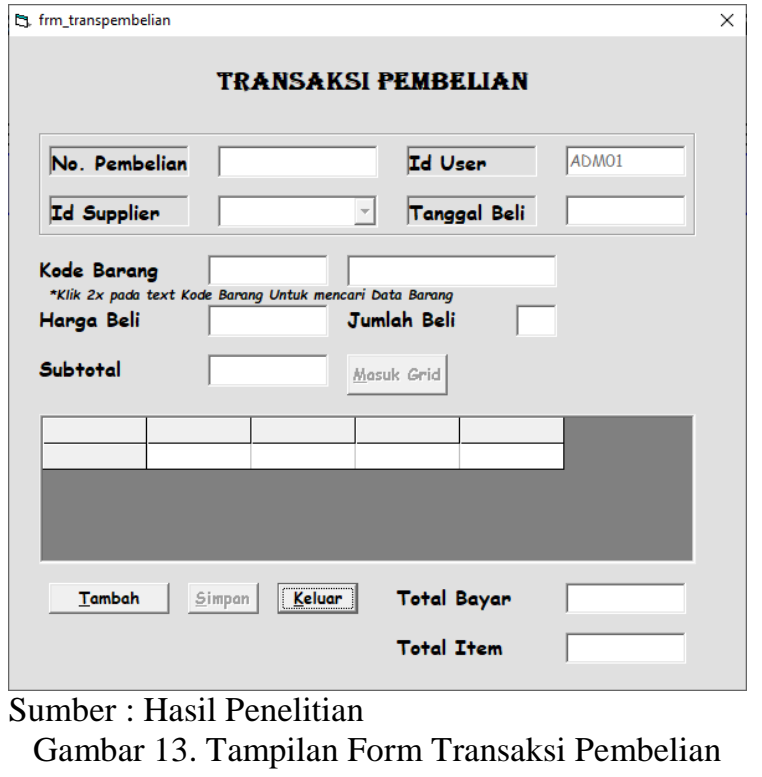

\section{KESIMPULAN}

Dengan adanya penerapan program penjualan dan pembelian alat tulis kantor pada CV. PUTRA MANDIRI dengan menggunakan Microsoft Visual Basic 6.0, maka proses transaksi penjualan dan pembelian akan lebih mudah dan ketelitian serta keakuratan data lebih terjamin. Serta dapat meningkatkan efektifitas dan efisiensi dalam proses pengolahan data. Penyimpanan data dengan menggunakan perangkat dan media penyimpanan komputer akan menjadi lebih aman, begitu pula jika kita ingin mencari atau mengubah kembali data-data yang diperlukan akan lebih mudah dan cepat. Serta dalam pembuatan laporan harian, mingguan dan bulanan menjadi lebih mudah. Penyimpanan data dengan menggunakan perangkat dan media penyimpanan komputer akan menjadi lebih aman, begitu pula jika kita ingin mencari atau mengubah kembali data-data yang diperlukan akan lebih mudah dan cepat. Serta dalam pembuatan laporan harian, mingguan dan bulanan menjadi lebih mudah serta Dapat meningkatkan efektifitas dan efisiensi dalam proses pengolahan data.

\section{REFERENSI}

Anhar. (2016). Kumpulan Source Code Visual Basic 6.0 untuk Skripsi. Jakarta: PT. Elex Media Komputindo.

Elyana, I. (2017). Decision Support System Untuk Kelayakan Pemberian Kredit Motor Dengan Menggunakan Metode Simple Additive Weighting Pada Perusahaan Leasing. Jurnal Pilar Nusa Mandiri, 13(1), 85-91. Retrieved from

http://ejournal.nusamandiri.ac.id/ejurnal/index. php/pilar/article/viewFile/341/273

Fridayanthie, E. W., \& Charter, J. (2016). Rancang Bangun Sistem Informasi Simpan Pinjam Karyawan Menggunakan Metode Object
Oriented Programming (Studi Kasus: Pt. Arta Buana Sakti Tangerang). None, 13(2), 63-70. Retrieved from http://ejournal.nusamandiri.ac.id/index.php/tec hno/article/view/207

Fridayanthie, E. W., \& Mahdiati, T. (2016). Rancang Bangun Sistem Informasi Permintaan Atk Berbasis Intranet (Studi Kasus: Kejaksaan Negeri Rangkasbitung). Jurnal Khatulistiwa Informatika, IV(June), 126-138. Retrieved from

https://ejournal.bsi.ac.id/ejurnal/index.php/kha tulistiwa/article/view/1264/1029

Kristanto, A. (2008). Perancangan Sistem Informasi dan Aplikasinya. Yogyakarta: Gava Media.

Kuryanti, S. J. (2016). Rancang Bangun Sistem ELearning sebagai Sarana Pemberlajaran Sandra. Jurnal Khatulistiwa Informatika, 4(1), 84-92. Retrieved from http://ejournal.bsi.ac.id/ejurnal/index.php/khat ulistiwa/article/view/1260

Ladjamuddin, A. B. Bin. (2013). Analisis Dan Desain Sistem Informasi. Yogyakarta: Graha Ilmu.

Madcoms. (2011). Aplikasi Program Terintegrasi dengan Visual Basic 6.0. Yogyakarta: Andi Offset.

Masrur. (2016). Pemrograman Web Dinamis menggunakan Java Server Pages dengan Database Relasional MYSQL. Yogyakarta: Andi.

Mulyadi. (2008). Sistem Akuntansi Cetakan ke Empat. Jakarta: Salemba Empat.

Mulyanto, A. (2009). Sistem Informasi KONSEP \& APLIKASI. Yogyakarta: Pustaka Belajar.

Nurahman, D., Prasetyo, F., \& Pratama, E. (2018). Perancangan Program Pengelolaan Transaksi Pembelian dan Penjualan Perlengkapan Olahraga Pada Abadi Sport. Jurnal Sisfokom (Sistem Informasi Dan Komputer), 7(1), 61. Retrieved from http://jurnal.atmaluhur.ac.id/index.php/sisfoko $\mathrm{m} /$ article/view/00010

Sukamto, R. A., \& Shalahuddin, M. (2014). Rekayasa Perangkat Lunak Struktur dan Berorientasi Objek. Bandung: Informatika.

Taufiq, G., Carolina, I., Janti, S., \& Rachman, K. (2015). RANCANG BANGUN APLIKASI SISTEM INFORMASI PENGGAJIAN PADA PT. "Z." SNIPTEK STMIK Nusa Mandiri, 4(2), 171-176. Retrieved from http://konferensi.nusamandiri.ac.id/prosiding/i ndex.php/sniptek/article/view/174 